\title{
Consistency in Organization and the Impact on the Well- being of Young Offenders in Correctional Facilities.
}

Nazirah Hassan \& Fauziah Ibrahim

To Link this Article: http://dx.doi.org/10.6007/IJARBSS/v11-i3/8914

DOI:10.6007/IJARBSS/v11-i3/8914

Received: 04 January 2021, Revised: 30 January 2021, Accepted: 11 February 2021

Published Online: 02 March 2021

In-Text Citation: (Hassan \& Ibrahim, 2021)

To Cite this Article: Hassan, N., \& Ibrahim, F. (2021). Consistency in Organization and the Impact on the Wellbeing of Young Offenders in Correctional Facilities. International Journal of Academic Research in Business and Social Sciences, 11(3), 19-25.

Copyright: (c) 2021 The Author(s)

Published by Human Resource Management Academic Research Society (www.hrmars.com)

This article is published under the Creative Commons Attribution (CC BY 4.0) license. Anyone may reproduce, distribute, translate and create derivative works of this article (for both commercial and non-commercial purposes), subject to full attribution to the original publication and authors. The full terms of this license may be seen

at: http://creativecommons.org/licences/by/4.0/legalcode

Vol. 11, No. 3, 2021, Pg. 19 - 25

http://hrmars.com/index.php/pages/detail/IJARBSS

JOURNAL HOMEPAGE

Full Terms \& Conditions of access and use can be found at http://hrmars.com/index.php/pages/detail/publication-ethics 


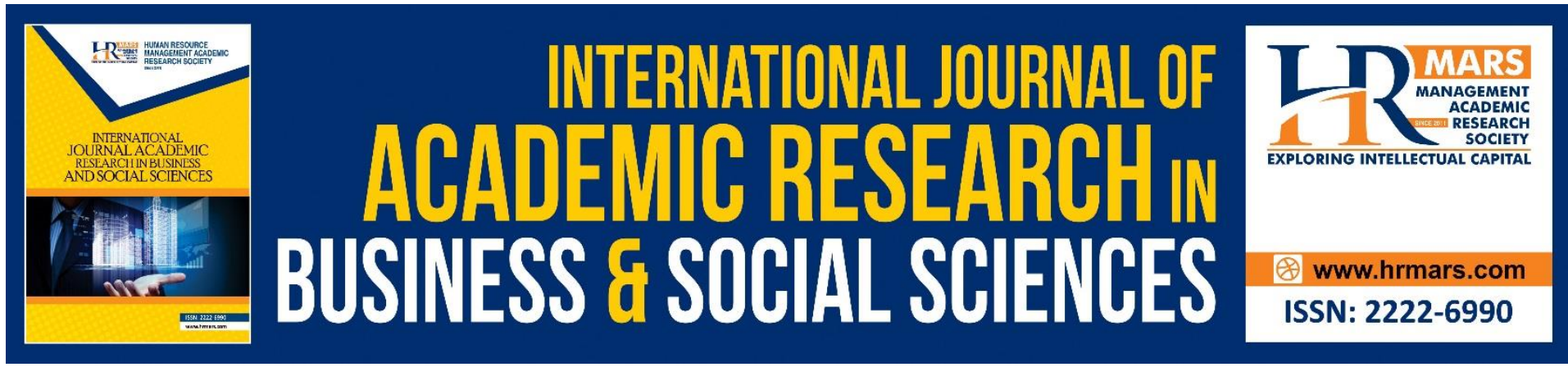

\title{
Consistency in Organization and the Impact on the Well-being of Young Offenders in Correctional Facilities.
}

\author{
Nazirah Hassan \& Fauziah Ibrahim \\ Centre for Research in Psychology and Human Well-being, Faculty of Social Sciences \& \\ Humanities, The National University of Malaysia, 43600 Bangi Selangor. \\ Email: nazirah@ukm.edu.my
}

\begin{abstract}
The key to an effective correctional treatment is the organization's quality. The quality of organization includes the consistency of a correctional system at managing security and delivering personal safety in correctional settings. This study seeks to explain levels of organizational consistency in juvenile correctional facilities. It further investigates how this dimension has an influence on the well-being of young offenders. The study comprised a survey completed by 289 male and female young offenders, aged 12 to 21 years old, in eight correctional facilities in Malaysia. The Measuring Quality of Prison Life (MQPL) was used to measure organizational consistency and the well-being of offenders. The findings demonstrate that majority of young offenders reported moderate levels of organizational consistency. Slightly more than half participants agree that the facilities are well-organised and well-controlled. Furthermore, the organizational consistency has significant influence on the well-being of young offenders in the correctional facilities. This study suggests that staff members play an important role in maintaining the quality of organization and thus creating a healthy correctional environment. This study has an impact on policy implementation in improving the well-being of young offenders in correctional facilities.

Keywords: Juvenile Offenders, Correctional Facilities, Organizational Consistency, Quality of Prison Life, Prison Management.
\end{abstract}

\section{Introduction}

Correctional organization can be understood as a set of interacting subsystems. Its subsystems are interrelated and work together to achieve a management strategy that works toward the goals of incarceration. Correctional management and operations can make a difference in how offenders behave. In the context of this study, an effective correctional management can be explained in at least three situations, including the control environment of a correction, good at delivering

personal safety and the quality of being coherent and transparent in delivering services and making decisions (Liebling, 2004). An effective management must be controlled and regulated by managers whose guidance and direction is consistent with organizational values and goals (Freeman, 1999). Both management and prisoners influence each other. Some believe that 
management is developed in response to prisoner behaviour, while others agree that management can actually elicit responses from the prisoner population (Morris et al., 2012). Liebling (2004) claims that authority is key to managerial functions in correctional facilities. Authority often appears in the same context as the power concept, and it serves to create and maintain total (or almost total) social control (Sykes, 1958). Nonetheless, it does not need to be exercised in order to exist.

Secondly, an effective management must be good at delivering personal safety. Safety is related to those aspects of a correction's environment concerned with the state of being free from or protected from danger and threat and which includes the role of staff in monitoring, regulating and enforcing the rules to facilitate a positive institutional environment (Sykes, 1958; Liebling, 2011). Threat and danger may include the pressure of trade, allegiances, drugs and victimisation (Liebling, 2004). A lack of supervision and control in correctional facilities can lead to perceived insecurity among prisoners (Bottoms, 1999). Thirdly, an effective management must consider the quality of being coherent and transparent in delivering services and making decisions. The treatments and services must address prisoners' offending behaviour and progress. In correctional facilities, treatment and service are for the purpose of rehabilitation. Rehabilitation is one of the most important purposes of incarceration, deeply rooted in the idea that prisoners can be returned to the community as law abiding citizens (Phelps, 2011). In Malaysia, too, the objective when imposing an order on incarcerating individuals should not be punitive. It aims primarily at helping prisoners to correct their behaviour and to become a productive and law-abiding member of society.

In Malaysia, the management of correctional facilities for children and young people is guided by the Child Act 2001. Under these regulations, all young offenders in correctional facilities have to be treated with adequate care and protection. That is, every child deprived of liberty must be treated with humanity and respect and in a manner that takes into account their needs, including needs related to education, vocational skills, meaningful treatments, accommodations, and contact with family members (UNICEF, 2013). The head, officers and staff members are responsible for providing offenders' daily needs as well delivering comprehensive treatment and care to them. They work closely and directly with young offenders, and they are responsible for creating a positive correctional environment by not only delivering the services but also through the development of supportive professional relationships with the offenders. Nonetheless, many of incarcerated offenders suffer from poor psychological health problems and develop maladaptive behaviours resulted from their negative experiences in the correctional facilities (Hassan, Kendrick \& Ibrahim, 2020).

The question of how far correctional facilities is effective in its aim to provide safety and protect both mental and physical well-being to incarcerated offenders is an important issue to discuss. Penologists suggest that correctional management play major role for creating a peaceful environment that is respectful of the human rights of those incarcerated (Coyle, 2020). Others also asserts that the consistency of correctional organization contributes to the health and well-being of prisoners (Liebling \& Crewe, 2012). Despite growing research on prisoner behaviours and the culture of prison communities, little attention has been paid to the aspects of correctional management. This study investigates young offenders' perception of organizational consistency in the correctional facilities and examine its influence on the well-being. 


\section{Methodology}

A survey study was conducted involving young offenders selected from five male correctional facilities and three female correctional facilities in peninsular Malaysia. A total of 289 young offenders selected and involved in the analysis with a 98.6 per cent response rate. The final sample for the survey study comprised 182 males young offenders (63.0\%) and 106 females young offenders (36.7\%) aged between 12 to 21 years old, with an average of 15.6 years old. The majority of young offenders $(87.9 \%)$ reported to serve their first custodial sentence and the rest (12.1\%) reported to be sentenced multiple times. More than half $(67.5 \%)$ reported to be sentenced more than a year and $32.5 \%$ less than 11 months. Their convictions ranged from property crimes (35.4\%), drug-related activities (18.3\%) to status offences (53.5\%).

Measuring the Quality of Prison Life scale (MQPL; Liebling, 2004) was used in this study. The MQPL is a self-report questionnaire that emphasise the importance of prisoner perceptions and experiences in understanding correctional life. It measures complex aspects of the social, relational and moral atmosphere of prison or other forms of correctional facilities. It consists of 147 statements that form 21 subscales, including the organizational consistency and the well-being subscales. Each subscale has between three and nine items, and all items are scored on a 5-point Likert scale (from 'strongly agree' to 'strongly disagree'). The organizational consistency subscale consists of six items and it was used to explain levels of organizational consistency. The well-being of young offenders was measured using the well-being subscale that consists of four items. Both subscales have strong consistency and each dimension carries reliability between .62 and .92 (Liebling et al., 2012).

The permission to conduct the study in eight correctional facilities was supported by the Malaysian Economic Planning Unit and approved by the Department of Social Welfare Malaysia. For the survey study, all eight correctional facilities were approached in different manners at particular periods of time. All young offenders in each institution were available at the time of the study invited to participate. A script containing detailed consent statement information was verbally explained to young offenders. The questionnaires were then distributed and completed in groups of 5 to 10 young offenders in a communal area of the facilities. The anonymity and the voluntary nature of the participation were guaranteed. Ethical approval for the study was granted by the University Ethics Committee (UEC), University of Strathclyde, Scotland (UEC14/40).

\section{Results}

Overall, it can be explained that majority of participants reported a moderate perception towards the organizational consistency. The total score of organizational consistency subscale is distributed between five and 30. The higher the score, the better the perceptions of organizational consistency. By using split analysis, participants are classified into three categories. Those scoring 10 and below are coded as having a 'negative' perception of organizational consistency, those scoring between 11 and 20 are coded as having 'moderate' perception of organizational consistency and those scoring 21 and above are coded as having 'positive' perception of organizational consistency. The result reveals that less than 20 per cent of participants reported positive perception of organizational consistency, 48 per cent reported moderate perception, and the rest reported negative perception. Table 1 further shows descriptive statistics of six organizational consistency items. The mean score of each item is distributed between one and five. This analysis shows that item 2 reports highest mean across six items, following by item 65 and 72 . Meanwhile, item 108 reports lowest mean with 
the score of 2.28. Overall, total mean score is 2.99 and this reveals that majority participants reported moderate perception of organizational consistency.

Table 1

Descriptive statistics of organisation and consistency items

\begin{tabular}{llcc}
\hline Item & Description & Mean & SD \\
\hline 2 & This is a well-controlled prison & 3.66 & 1.21 \\
$40^{*}$ & To get things done in prison, you have to ask and ask and ask & 2.42 & 1.22 \\
65 & This prison is well organised & 3.65 & 1.10 \\
72 & This prison is good at delivering personal safety & 3.65 & 1.23 \\
$77^{*}$ & You never know where you stand in this prison* & 2.31 & 1.23 \\
$108^{*}$ & There is not enough structure in this prison* & 2.28 & 1.25 \\
\hline & Total mean score for organizational consistency subscale & 2.99 & .57 \\
\hline
\end{tabular}

* Reversed scoring item.

Turning to the well-being subscale, majority of participants also reported moderate perceptions towards the well-being in the correctional facilities. The total score of the wellbeing subscale is distributed between five and 20 . The lower the score, the better the perceptions of well-being. Those scoring seven and below are coded as having a 'positive' perception of well-being, those scoring between eight and 13 are coded as having 'moderate' perception of well-being and those scoring 14 and above are coded as having 'negative' perception of the well-being. The result reveals less than 28 per cent of participants reported positive perception of well-being, 55 per cent reported moderate perception, and only minority reported negative perception. Table 2 illustrates descriptive statistics of four wellbeing items. The total mean score of each item was distributed between one and five. The lower the score, the better the perceptions of well-being. Overall, participants reported moderate perception towards all items with mean score between 2.24 and 3.08 . Item 82 reports lowest mean across the four items. This reveals majority of participants agreed that their experiences in the facilities was less painful. Item 106 reports highest and this means that majority participants agreed that imprisonment feels very much like a punishment.

Table 2

Descriptive statistics of well-being items

\begin{tabular}{llcc}
\hline Item & Description & Mean & SD \\
\hline 57 & My experience of imprisonment in this particular prison & 2.24 & 1.15 \\
& has been stressful. & 2.64 & 1.19 \\
79 & I feel tense in this prison. & 2.27 & 1.18 \\
82 & My experience in this prison is painful. & 3.08 & 1.47 \\
106 & My time in this prison feels very much like a punishment. & 2.55 & 1.21 \\
\hline & Total mean score for well-being subscale & & \\
\hline
\end{tabular}

Pearson correlation analysis demonstrates a significant negative relationship between the organizational consistency and the well-being with $r=-.127, p<.05$. Nonetheless, the degree of the relationship is small. Furthermore, regression analysis reports that organizational consistency has an influence on the well-being with $b^{2}=-.18$., $p<.05$ This value indicates that there is a corresponding decrease of 1.8 per cent in the well-being for a single unit increase in the perception of organizational consistency. Overall, the perception of 
organizational consistency predicts the well-being of young offenders in correctional facilities.

\section{Discussion \& Conclusion}

This study discovers that correctional organization has an influence on the well-being of an individual offender, and this can make a difference in how offenders behave. In particular, this study confirms that the inconsistency in organization contributes the stressful and painful experiences in the correctional facilities. The inconsistency in organization can also lead offenders to view the system as illegitimate (Liebling \& Crewe, 2012). This situation can be explained in relation to the concept of bureaucratic legitimacy. Bureaucratic legitimacy is related to the staff-prisoner relationship, primarily reflected in the clarity of decisions made about offenders, manifest in the use of authority by officers and staff members (Liebling, 2004). Young offenders who attribute less legitimacy to the bureaucratic system perceive that power operated in correctional facilities as inconsistent and unpredictable. Some offenders that deal with inconsistent bureaucratic procedures are fraught with difficulties. Some offenders are very critical of the daily operations of correctional facilities. The difficulties of daily operations led to an unwillingness to comply with the system, and thus less likely to accept institutional systems as legitimate (Tyler, 2006).

Within correctional facilities, perceptions of legitimacy can be related to perceptions of fairness (Tyler, 2006). Indeed, both play an important role in shaping young offenders' wellbeing in the corrections. Legitimacy means, broadly, the fairness of authority (Liebling, 2004). The legitimate exercise of authority depends on offenders' experiences of the fairness of their treatment, which includes procedures and punishment, but also the manner of their treatment (Tyler, 2006). It has been argued that only legitimate social arrangements generate normative commitments towards compliance (Sparks, 1996). In contrast, the presence of a lower degree of legitimacy can give rise to disobedience.

Critics of correctional facilities argue that power within the correctional facilities is inherently non-legitimate. It can be argued that increasing levels of perceived illegitimacy result primarily from the use of unfair, harsh or unduly excessive punishment and the lack of exercise of discretion or too much of it, which can negatively affect staff-prisoner relationships. Scholars describe unfair punishment and procedures as a form of abuse and disrespect. For prisoners with a high sense of superiority, the experience of abuse and disrespect in correctional facilities is perceived as a superiority threat. This threat may interrupt one's sense of worth or values, thus negatively affect his or her well-being.

It should be understood that correctional facilities impose higher levels of situational control than are usually present elsewhere (Sparks \& Bottom, 1995). The task of controlling requires the use of authority and the pursuit of order. These in many ways are highly visible. Tyler (1990) argues that 'the effectiveness of legal authorities ultimately depends on voluntary acceptance of their actions' (p. 24). When power is applied more fairly and thus the decision making in the correctional facilities is able to be navigated (Aas, 2004) then normative commitments towards compliance, conformity and cooperation are generated. By contrast are inconsistent routine and the lack of clear structure and decision making, bloated organizational dysfunction and collapse with bureaucracy. In this study, the lack of clear structure and decision-making are assumed to manifest a lack of clear authority. Some offenders believe that the lack of clear authority is perceived as a psychological threat. That is more likely to stimulate the denial of legitimacy and thus create resistance (Crewe, 2009). 
To conclude, organizational consistency play an important role to an increase perceive of bureaucratic legitimacy. Correctional facilities are central sites for the exercise of disciplinary power, in which power is centralized in the hands of the officers and delegated to staff members to exercise upon prisoners. Officers or staff may have power in an institution through their ability to control inmates. They generally control offenders through the accomplishment of order, achieved through multiple means, for example, the daily application of institutional rules, punishment or sanctions and procedures. Institutions historically have operationalised the pursuit of order in a coercive fashion. The consistent use of coercion may generate minimal levels of perceived or attributed legitimacy under certain conditions (Liebling \& Crewe, 2012).

\section{References}

Aas, K. F. (2004). From narrative to database: technological change and penal culture. Punishment \& Society, 6(4), 379-393.

Coyle, A. (2020). The management of high-security prisoners. alternatives to solitary confinement. In, J. Lobel \& P. S. Smith (Eds.), Solitary confinement: effects, practices, and pathways toward reform (pp259-277). New York: Oxford University Press.

Freeman, (1999). Correctional organization and management: public policy challenges, behavior, and structure. Massachusetts: Butterworth-Heineman.

Hassan, N., Kendrick, A., \& Ibrahim, F. (2020). The quality of life of young offenders in juvenile justice institutions. International Journal of Psychosocial Rehabilitation, 24(04) 4193-06

Liebling, A. (2004). Prisons and their moral performance: a study of values, quality, and prison life. Oxford, England: Oxford University Press.

Liebling, A. (2011b). Moral performance, inhumane and degrading treatment and prison pain. Punishment \& Society, 13(5), 530-550.

Liebling, A., \& Crewe, B. (2012). Prisons beyond the new penology: the shifting moral foundations of prison management. In J. Simon \& R. Sparks (Eds.), The handbook of punishment and society. London: Sage.

Morris, R. G., Carriaga, M. L., Diamond, B., Piquero, N. L., \& Piquero, A. R. (2012). Does prison strain lead to prison misbehavior? An application of general strain theory to inmate misconduct. Journal of Criminal Justice, 40(3), 194-201.

Phelps, M. S. (2011). Rehabilitation in the punitive era: the gap between rhetoric and reality in US prison programs. Law \& Society Review, 45(1), 33-68.

Sparks, J. R., \& Bottoms, A. E. (1995). Legitimacy and order in prisons. British Journal of Sociology, 46(1), 45-62.

Sparks, R. (1996). Penal 'austerity': the doctrine of less eligibility reborn?. In P. Francis \& R. Matthews (Eds.), Prisons 2000: an international perspective on the current state and future of imprisonment. London: Palgrave Macmillan.

Sykes, G. M. (1958). The society of captives: a study of a maximum security prison. Princeton, NJ: Princeton University Press.

Tyler, T. R. (2006). Restorative justice and procedural justice: dealing with rule breaking. Journal of Social Issues, 62(2), 307-326.

Tyler, T. S. (1990). Why people obey law. New Haven, CT: Yale University Press. 